\title{
Making sense and identifying aspects of Indian culture(s) in organisations: Demystifying through empirical evidence
}

\author{
Vijay Pereira and Ashish Malik
}

\section{Introduction and Rationale for this Special Issue}

What is India? How does one describe India? How do Indians experience India? How do others experience India and Indians? By their very nature, most experiences (including of culture) can be regarded as highly subjective. Do differences in experiences therefore create problems in managing people in an increasingly globalised world? How do Indians perceive others? Do postcolonial influences colour their/ our understandings of the cultural ways of the 'other'? Understanding differences in what constitutes 'Indianness' and 'otherness' is critical to the study of managing people across borders, including those working in India in large multinational corporations. Then again, how does one delineate culture in India? And is there empirical evidence that identifies cultural aspects in Indian or foreign organisations operating in India? These were the pressing and pertinent questions we asked ourselves when this special issue was being planned and conceived, two years ago.

We are not the only scholars who have asked these questions about India. As long ago as 1930 William Durrant, an American historian, defined India as follows:

"India was the motherland of our race, and Sanskrit the mother of Europe's languages: she was the mother of our philosophy; mother, through the Arabs, of much of our mathematics; mother, through the Buddha, of the ideals embodied in Christianity; mother, through the village community, of self-government and democracy. Mother India is in many ways the mother of us all...' (Durant, cited in Avari 2007, 18)

Though seen as 'hyperbole in praise of India', by Avari $(2007,18)$, Durrant continued in 1935 to explain the lack of knowledge scholars and students had of India as a civilisation:

'....Nothing should more deeply shame the modern student than the recency and inadequacy of his acquaintance with India... This is the India that patient scholarship is now opening up like a new intellectual continent to that Western mind which only yesterday thought civilization an exclusive Western thing." (Durant 1935, 391)

We found a status quo in terms of research on culture in India, and especially on culture in organisations in the Indian context and decided to pursue research in this direction. In 2013 this then led to our call for papers, titled "East is East? Understanding aspects of Indian culture(s) within organisations", and here we are in 2015 presenting this special issue as an outcome of that process and exercise. The issue is a modest attempt to contextualize Indian discourses on modernity at an economic, cultural and social level; and to ignite a debate leading to a trend in researching in this extremely complex and challenging, but also interesting and stimulating area of study.

Apart from the broad rationale and set of questions raised above, there are several other rationales for this issue. First, we as editors are also former Indian nationals and natives, having now settled in the UK and Australia, respectively, for the last 15 years. In our professional and personal lives as first generation economic migrants we continue to face 
several questions that lead to the need for a greater understanding of our cultural roots and philosophy. Hence, comments such as 'you think like an Indian', or questions such as 'why do you do things this way?' led us to reflexively ponder on reasons for both the comments/questions as well as the answers and ways to demystify them. Second, there is still a large void in the literature when it comes to culture (and its consequences) in Indian organisational contexts, be it Indian or foreign organisations operating in India or Indian organisations operating globally. With India poised to be the second largest (and still growing) economy globally, its impact is profound, and hence the importance of understanding its culture/s becomes imperative and timely. When compared to similar cultural research in other 'emerging' economies, such as say China (Tsui, Wang and Xin 2006), there is certainly a gap and hence cultural research on India is much needed. That said, third, there are many viewpoints, both ancient and modern, of the 'idea of India' (Khilnani 2012), its history (Jabbar 2009) and its culture (Pereira and Malik 2015a). However, the need for empirical evidence about Indian cultural aspects in an organisational context is significant. Thus, such empirical research could in a sense either confirm the several extant ideas about or perspectives on Indian culture, or prove that they are inconclusive myths. Further, such empirical work can develop theorisation and discussion leading to future research directions, something that we aim to partly achieve through this special issue. Finally, bringing our disciplinary perspective, we are of the view that without a thorough understanding of cultural aspects (of Indianness and otherness), the design and implementation of organisational aspects such as human resource management and employment relations practices (local and international) will often be ineffective. Indeed this aspect has been borne out in a recent study of 'Indian' HRM practices (Bandyopadhyay 2011, 2015). Bandyopadhyay argues that understanding of Indianness is the key to success of various human resource management interventions and practices in this context.

In what follows, we discuss the emergence of the Indian economy in the global space, starting with a historical perspective. Thereafter we discuss the Indian perspective on culture and organisations and then portray the positioning of this special issue, its contributions and future research directions.

\section{Emerging or Re-emerging India in the global economy? A historical perspective}

Where did and does India stand in the global economy? Oftentimes the popular press, policy discourses from the World Bank and scholars refer to India and China as the newly emerging economies. However, historically neither nation is really emerging, but rather re-emerging. In terms of India's share of world GDP, in 1 AD, it held the majority, China being a close second, with Italy (or the former Roman Empire) in third place, as figure 1 suggests. Collectively in fact India and China continued their global GDP domination until around the 1870 's. 


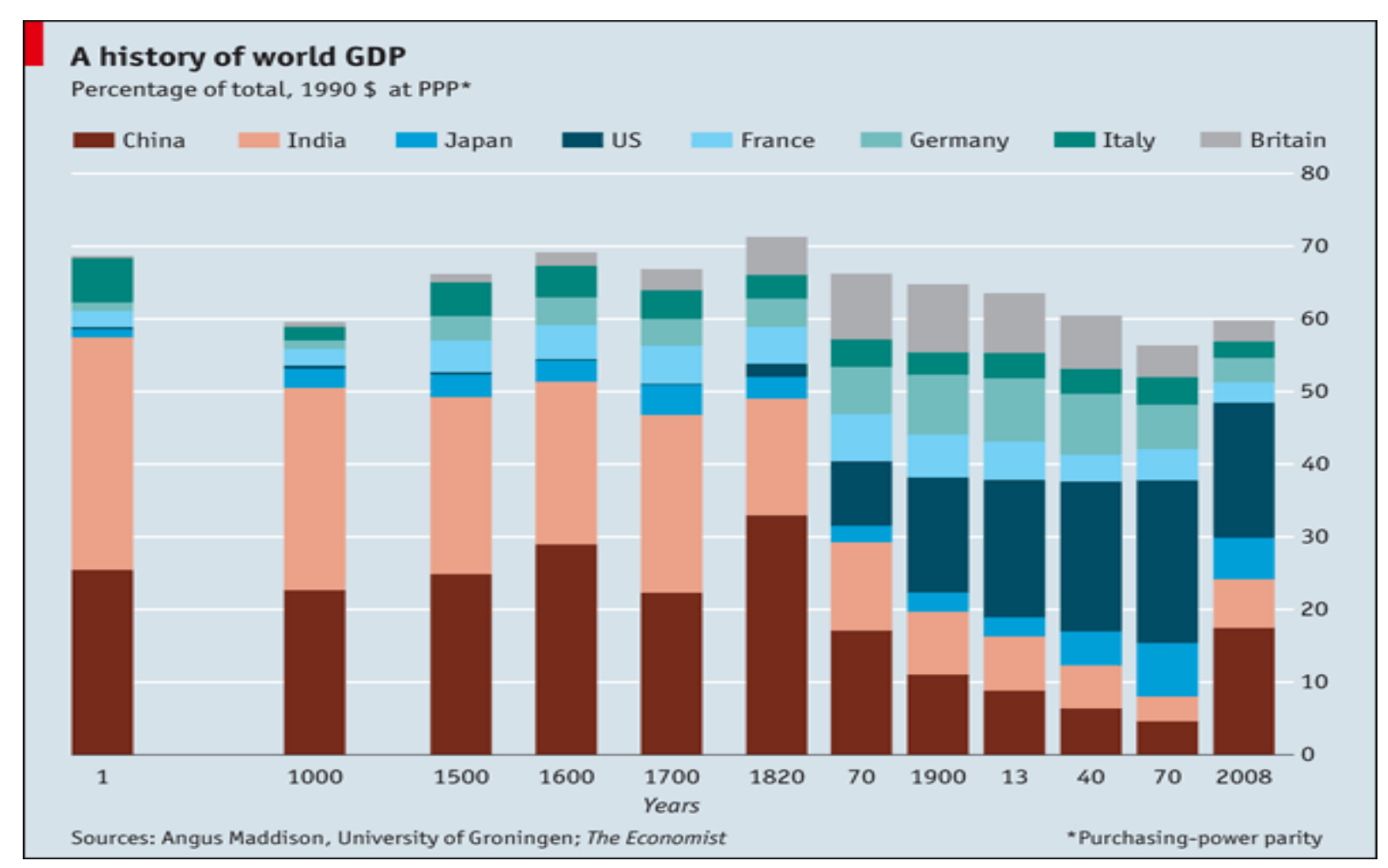

Figure 1: The History of World GDP (Source: The Economist, 2010, http://www.economist.com/node/16834943)

Figure 1's data, compiled by the late Angus Maddison, an economist, suggests in fact that China and India were the biggest economies in the world for almost all of the past 2000 years. Historically, the famous Silk Road (where trade took place between China and India, Mesopotamia, Persia, Egypt and Rome), and the Amber Road (for transporting amber from the North Sea and Baltic Coasts across Europe to Italy, Greece, the Black Sea region and Egypt) connected India with the global economy of the time. Thereafter, Columbus's discovery of America in 1492 is believed to have led to capitalism. Factually, Columbus actually went in search of a shorter route to India when he discovered America.

Thereafter from the 1870's onwards colonisation took place, and as is also depicted in figure 1, the share of global GDP of countries such as Britain, Germany and France rose. During this time the ugly slave trade and opium trade were rife, especially the latter in India. The idea of exporting opium to China started with Warren Hastings (the first governor general of British India) in 1780, in order to settle the balance of payments. This single 'product' (opium) accounted for about $20 \%$ of Indian revenues which was commandeered by India's colonial British rulers (Ghosh 2008). In fact these revenues don't account for the entire profits generated; there was shipping and many ancillary industries around opium and hence this product was a 'cash cow' for the British rulers. Could it be argued that India's lack of understanding of the 'other' (in this case Britain's culture and practices of managing the colonies during its rule in India), amongst other factors, contributed to the economic success and consequently Britain's growth and prominence in the global economic landscape? Also over time greater understanding of the 'other' culture could be one of other explanations for witnessing a re-emergence of India as an economic power. For example, a recent study by Buckley, Enderwick, Forsans, and Munjal (2013) suggest that Indian firms have benefitted 
from colonial linkages, through enhanced cultural understanding and ties with Britain, when it came to international expansion.

Multinational corporations (MNCs) have, furthermore, always been key players in global businesses. Historically, the Honourable East India Company (HEIC) and the Dutch East India Company (Vereenigde Oostindische Compagnie or VOC) were privately owned commercial English ${ }^{1}$ and Dutch ${ }^{2}$ organisations respectively. This of course has often been argued to further promote the global spread of capitalism. HEIC represented the start of British imperialism and colonisation in India. The VOC traded with $17^{\text {th }}$ century East India (modern Bangladesh), Iran, Malaysia, Taiwan, Thailand and Southern China. It had an establishment of merchant ships and employees, and also a fleet of 40 warships and a 10,000 strong army. In comparison, one example of a modern MNC is the TATA Company, an Indian MNC that is said to be the largest manufacturing employer in the UK currently, with acquisitions such as Tetley, the former British Steel, Jaguar and Land Rover - to name but a few (Pereira 2012).

Further, technological advances in sea, air, manufacturing, printing, postal services etc. led to greater internationalisation: e.g. Europe and North America were connected by underwater telegraph cables in 1866 as was the case with the British Empire, with its colonies (1890). The same can be said of the technological advancements in the area of information and communication technology (ICT) in the modern world; as we will see in the case of the role of India in the global information technology and offshoring industry later.

Apart from being the fastest growing economies in the world, India and China have historically been, and continue to be, the world's most populated countries. Figure 2 portrays this. There are arguments that these two countries were the major economies historically because they had the largest populations and that, up until 200 years ago, population size was a dominant factor in economic output (e.g. Kuznets, 1960).

\footnotetext{
${ }^{1}$ HEIC had 125 merchant shareholders.

${ }^{2}$ The VOC was the world's first MNC, with shareholders from Germany, Belgium and Luxembourg.
} 


\section{Population}

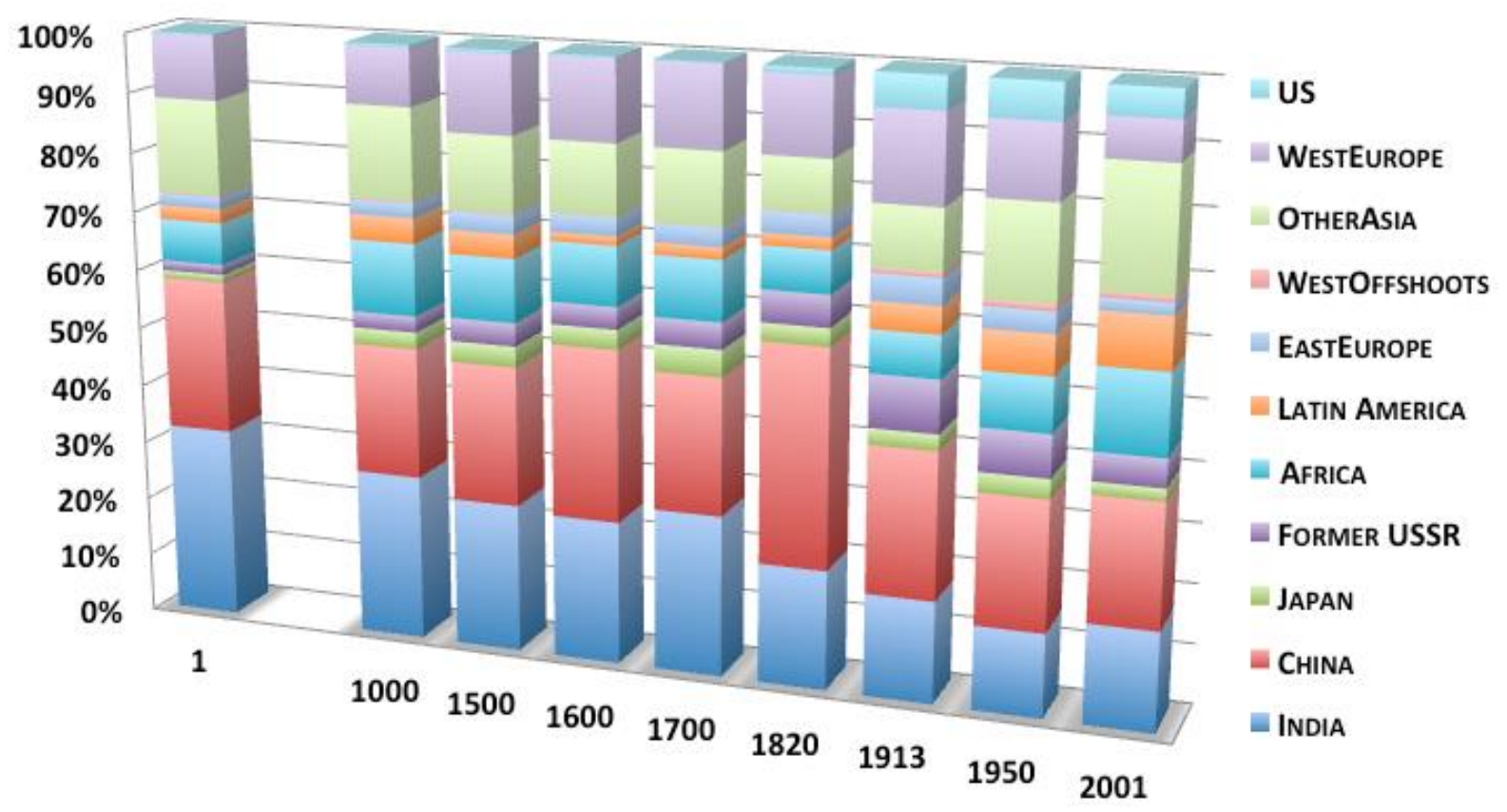

Figure 2: Historical Distribution of World Population (Source: The Economist, 2010, http://www.economist.com/node/16834943)

Between them, India (1.2 billion) and China (1.3 billion) currently account for two thirds of the world's population of just over 7 billion. And the people of these countries are today not only active participants in the global business value chain, as producers, but are also major consumers. An example of the Indian case is shown by the McKinsey Global Institute's McKinsey Report 2007 (Pereira and Kalakoti 2014), where the Indian market is divided into five categories, as depicted in table 1.

\begin{tabular}{|c|c|c|c|}
\hline \multirow{2}{*}{$\begin{array}{c}\text { Category } \\
(\text { Earnings in US\$) } \\
(\mathbf{p m}=\mathbf{p e r} \text { month) }\end{array}$} & \multicolumn{3}{|c|}{ Number of Households in India (in million) } \\
\cline { 2 - 4 } & Year 2005 & Year 2015 & Year 2025 \\
\hline $\begin{array}{c}\text { Globals } \\
(\text { earn }>\$ 1000 \mathrm{pm})\end{array}$ & 1.2 & 3.3 & 9.5 \\
\hline $\begin{array}{c}\text { Strivers } \\
(\text { earn } \$ 500 \text { to } \$ 1000 \mathrm{pm})\end{array}$ & 2.4 & 5.5 & 33.1 \\
\hline $\begin{array}{c}\text { Seekers } \\
(\text { earn } \$ 200 \text { to } \$ 500 \mathrm{pm})\end{array}$ & 10.9 & 55.1 & 94.9 \\
\hline $\begin{array}{c}\text { Aspirers } \\
(\text { earn } \$ 90 \text { to } \$ 200 \mathrm{pm})\end{array}$ & 91.3 & 106.0 & 93.1 \\
\hline $\begin{array}{c}\text { Deprived } \\
(\text { earn }<\$ 90 \mathrm{pm})\end{array}$ & 101.1 & 74.1 & 49.9 \\
\hline
\end{tabular}

Table 1- Categorisation of the Indian Market 


\section{(Source: Pereira and Kalakoti, 2014 - presenting McKinsey Global Institute's 'McKinsey Report' 2007)}

As predicted in the last column, by 2025, the middle classes in the Indian market (Strivers and Seekers, earning between US\$200 to 1000 per month) will have grown to 33.1 and 94.9 million households respectively, thereby also halving the Deprived class (earning less than US\$ 90 per month) from 101.1 million households in 2005 to 49.9 million households in 2025.

It is the recent economic liberalisation of China and India which has led to their resurgence. However, as compared to the past (as discussed earlier), in modern India and China, the service sector plays a big role in both economies. $40 \%$ of China's and $55 \%$ of India's contribution to GDP comes from services, with the US and Japan at 79\% and 74\% respectively (Economywatch). Table 2 depicts these data. As we can see there, compared to the world's 'developed' countries, both India's and China's GDP are still heavily dependent on agriculture, but their percentages in industry and services are steadily increasing. Thus, if China is the world's manufacturing or industrial hub, India is the world's back office. And with the current Indian government's initiative to 'Make in India', industry in India could increase.

\begin{tabular}{|c|c|c|c|}
\hline Countries & Services \% & Industrial \% & Agriculture \% \\
\hline USA & 78.5 & 20.6 & 0.9 \\
\hline China & 39.5 & 49.5 & 11 \\
\hline Japan & 73.3 & 25.2 & 1.5 \\
\hline India & 55 & 28.4 & 16.6 \\
\hline Germany & 69.5 & 26.9 & 0.9 \\
\hline
\end{tabular}

Table 2: Contribution to GDP (estimate 2012) in the world's largest economies by sector (Source: Economywatch)

In terms of services, modern India has a major share of the global information technology (IT) and business process offshoring (BPO) sectors. Significantly, moreover, although modern in practice, the concept of doing business where it is better, faster and cheaper, has always been propagated. For example, Adam Smith wrote over 200 years ago that 'It is the maxim of every prudent master of a family never to attempt to make at home what it will cost him more to make than to buy' (cited by Paul and Amawi 2013, 60). Further, 'The larger the enterprise, the farther the division of labour may be carried. This is one of the principal causes of large manufactories' (Adam Smith again, cited in Mill 1965, 131).

To give a clearer idea of scale in this regard, in 2012, the overall Indian IT/BPO aggregate revenues exceeded US\$ 100 billion, with exports alone exceeding US\$ 84-87 billion in 2014 (NASSCOM 2014; Pereira and Budhwar 2015). As a proportion of national GDP, the sector revenues have grown from 1.2 per cent in 1998 to over 8.1 per cent in 2014 (NASSCOM 2014; Pereira and Budhwar 2015). In 2012, India led the world in terms of the number of quality certifications achieved by centres in any single country in the global IT software 
development and services industry (NASSCOM 2012). The Indian IT/ BPO industry comprises over 16,000 firms, including over 3,000 software product firms, and these account for over 90 per cent of the global incremental growth of US\$11-12 billion in revenues (NASSCOM 2014; Pereira and Anderson 2012; Pereira and Budhwar 2015, Pereira and Malik 2015 a, b; Malik 2015; Malik, Sinha and Blumenfeld 2015; Malik and Rowley 2015).

In fact so profound has the influence of India been on this global industry that it is not surprising that the majority of submissions to this special issue were based on the Indian IT industry, as we discuss below. We begin by providing a brief discussion of various approaches to understanding culture and the problems that several approaches pose in furthering our understanding. We use a recent framework for classifying culture studies for situating the contributions covered in this special issue.

\section{Culture and Organisations: The Indian perspective}

In terms of understanding aspects of Indian culture/s in organisations, the challenge lies in making appropriate choices. The options in cross-cultural management research are wide and grounded in several disciplinary orientations such as sociology, anthropology, psychology and business and management. In cross-cultural psychology, for example, it is important to study the roles of culture and self, employing self-construal theory (Markus \& Kitayama 1991) to assess culture's impact on emotion, cognition and motivation. The basic premise of this theory is that certain cultures and value systems are individualistic or collectivistic and as such individuals in such societies have independent and interdependent self-construals. While this sounds like an intuitive and plausible approach, there are several challenges inherent in making such assumptions about nation states. For example, Oyserman, Coon, and Kemmelmeier (2002) argue that, for most Americans, being individualistic typifies Americanness in the same vein as having a collectivist orientation typifies being an Asian. They further argue that there are differences in individualism within America. For example, they note that European Americans are no more individualistic than African Americans or Latinos, and no less collectivistic than Japanese or Korean Americans.

Thus one needs to be very cautious in making assumptions when studying culture. It also requires a careful delineation of related and overlapping concepts such as identity, business systems, institutions and practices (Giorgi, Lockwood and Glynn 2015). In their extensive review of thirty years of literature on culture and related concepts, Giorgi et al. (2015) categorise five prominent ways in which culture has been theorised in the management literature. They identify these as values, stories, frames, toolkits, and categories and organise these into a framework or model that hinges on values and toolkits as 'anchors'.

First, Giorgi et al. $(2015,5)$ suggest that culture is conceptualised as values in terms of "what we prefer, hold dear, or desire". This has its roots in anthropology and sociology (Greetz 1973; Weber 1958) and the concept focuses on how culture helps in providing meaning for cognition and action. Second, Giorgi et al $(2015,6)$ define culture as frames, 'filters or brackets that delimit what we pay attention to'. They argue that such an approach relies on social constructions of culture, highlighting its highly subjective nature. Third, Giorgi et al $(2015,5)$ define stories as "Verbal or written narratives with causally linked sequences of events that have a beginning, a middle, and an end". For example, the Panchatantra (the five principles or techniques), an Indian classic on developing an understanding of polity, has been passed on by generations of Indians, mostly through oral narration of stories, since 300 
BC (Ryder 1925). These stories depict aspects of Indian culture and political approaches and have travelled to different parts of the world, often assuming adaptations of the key messages. The names and characters often change and the orator of the stories exercises flexibility to adapt the story the context without compromising on the learnings. Fourth, Giorgi et al (2015, 7) define categories as "social constructions or classifications that define and structure the conceptual distinctions between objects, people and practices". They suggest categories provide objectivity, inclusion and legitimacy, often suggestive of the property of sameness or isomorphic conditions for a given category of for example, an object, people or practices. Finally, Giorgi et al $(2015,6)$ define toolkits as 'Sets or "grab bags" of stories, frames, categories, rituals, and practices that actors draw upon to make meaning or take action'. Such a conceptualisation has high practical relevance for people to make sense of the phenomena they experience.

\section{Positioning of the Special Issue and Contributions}

We did not have any prescribed worldview or preferences for one frame over another in our minds in seeking contributions to the special issue. What we did focus on was a broad set of theoretical concepts that were found in the wider literature to have an impact on cultural understanding in an Indian context. We also found Giorgi et al.'s (2015) theorisation a useful frame to situate the contributions in this issue, which we now outline.

The first paper by Jasmin Mahadevan, titled 'Caste, purity, and female dress in IT India: Embodied norm violation as reflexive ethnographic practice', captures both culture as values and culture as a frame (Giorgi et al. 2015). Mahadevan's paper focuses on two field-related phenomena, 'adhering to vegetarianism' and 'dressing the female body'. By using norm violation as a reflexive ethnographic practice, she brings out novel theoretical insights that would not normally be extracted through analysis of text, discourse and cognition. By introducing norm violation in the research setting as regards the phenomena of food and dress, the researcher uncovers insights on embodied purity and caste in the Indian IT industry. The findings highlight, for example, the 'specific anatomy of power by which female bodies are disciplined in IT India' (Mahadevan, this issue, 20). The blending of conflicting choices around 'modernity' and 'purity' offers an important empirical contribution of the powerful discourses that exist in the sector. The paper also offers a methodological contribution by highlighting that norm violation and preparing the researcher to carefully choose the scenarios for norm violation can be an exciting new area for cultural research.

The second paper by Pratima Sambajee, entitled, 'Rethinking non-traditional resistance at work: The case of the Indian Diaspora in Mauritius' provides a novel approach of studying non-traditional forms of resistance through Homi Bhabha's theoretical lens on postcolonialism. Giorgi et al's (2015) conceptualisation of culture as values and culture as stories is approximately related and relevant here. The study's context, Mauritius, is well chosen to study this phenomenon as Sambajee highlights a vast majority of its extremely diverse population (two-thirds Indian and the remaining are from African decent (Creoles) or of Chinese origin) is affected by postcolonial influences of the British and French colonisation in the $18^{\text {th }}$ century. More specifically, by employing Bhabha's concepts of mimicry, ambivalence and hybridity, Sambahjee provides rich insights through a two-stage qualitative study. Preliminary focus groups with managers in the hospitality industry are 
followed by 20 ethnographic accounts of Indo-Mauritians in the hotel industry. Despite a generation of settlement, a number of Indo-Mauritians still engage with their Indian roots and use language, materiality and sacred space to develop novel non-traditional forms of resistance in dealing with unequal power relations in their new home, Mauritius.

The third paper by Minna Salminen-Karlsson entitled, 'Expatriate paternalistic leadership and gender relations in small European software firms in India' also focuses on the Indian IT industry. It highlights gendered relations that exist in the context of subsidiaries of European software firms operating in India. The study offers insights into how European managers adapt their paternalistic leadership style to the Indian context to manage gender issues in recruitment and selection, attrition, working hours and leave policies. Using qualitative data from two European case study firms, Salminen-Karlsson highlights the importance of adaptation of leadership style by European managers to effectively manage gender issues in the subsidiary operations. The result is the emergence of a win-win culture that is appreciated by employees at the Indian subsidiary. This contribution is akin to Giorgi et al's (2015) conceptualisation of culture as a value and frame.

The final paper by Francis Laleman, Vijay Pereira and Ashish Malik, titled, 'Understanding cultural singularities of 'Indianness' in an intercultural business setting' presents exploratory research to tease out ten cultural singularities that typify Indianness. This is different from the commonly used Hofstedian or similar cultural value dimensions. These existing frameworks do not sufficiently describe or explain the modern intercultural dynamics in today's globalised organisations. Hence, the authors highlight their approach and build on existing knowledge of cultural dimensions. This paper provides a much more nuanced and contextually grounded understanding of the singularities that are relevant for future researchers studying Indian culture. Indianness, Laleman et al. argue, is a set of attributes that individuals have acquired through their socialisation, being part of, or by belonging to this group. It is these singularities that distinguish the group from the 'other'. Set in the context of intercultural training interactions in an Indian IT MNC subsidiary in Belgium, Laleman et al. identify the following ten cultural singularities: emotions towards the national anthem, importance of relationships, food, ancestral classification based on competence, upholding the established rule, vyahvahar or expectations with regard to outspokenness, justice, gurutva or gravitas of the guru, karma, and jugaad or frugal innovation and problem-solving. It is expected, they argue, that Indians will score very high on these singularities and global businesses can use these in developing a much more nuanced understanding of Indianness. This contribution fits the description of 'toolkits' by Giorgi et al (2015).

\section{Conclusions and future research directions}

There are several converging and diverging themes that emanate from this special issue. As expected, the call attracted a lot of attention globally, and we were overwhelmed with interest, enquiries, responses and submissions. Through our review of all submissions received we note that there appears to be a remarkably high level of interest in studying aspects of Indian culture in multinationals operating in and outside of India. In particular, there is interest in studying cultural interactions in subsidiaries of Indian MNCs. This might be indicative of the number of Indians living and working overseas (including us) as members of the diaspora who are keen to maintain close ties with the development and growth or lack thereof of their motherland. The need to be seen as connected to their home is 
perhaps indicative of their Indianness. Moreover, three of the four accepted contributions focus on the Indian IT industry. It is not surprising to see a renewed interest in this research context, even from contributors who are not native Indians, as offshore outsourcing is a paradigm shift in global capitalism that has affected several nations in a number of ways. This research context will continue to be of interest to scholars as it presents us with a perfect setting to study culture, cross-cultural management and how aspects of Indianness affect success or failure in the design and implementation of a range of management practices. Additionally, we found that most contributions demonstrated the impact of ancient and modern historical events in strengthening the cultural singularities of Indianness. Still further, another theme common to the contributions was the importance of language, religion and ancient scriptures in modern day management in India.

The collection also opens up several new research directions. For example, introducing norm violation in ethnographic research could result in adoption of changes to research methodology, potentially yielding new theoretical concepts. Additionally, by adopting an inclusive theoretical approach from ancient and modern history, scholars can analyse the influence history has in the leadership and management practices of contemporary organisations. Finally, testing and developing measures of Indianness is another promising area of inquiry that will potentially open up a new stream of research.

In closing, and as the previous paragraph suggests, we emphasise that our contribution to understanding aspects of Indian culture/s in organisations is only the tip of the iceberg, as this topic is complex, mammoth and multifaceted. Thanks are, of course, due to all of the authors for such interesting and significant papers and for bearing with us through the reviewing process. We also want to thank the reviewers for their constructive feedback, as they worked tirelessly to complete the reviews on time - especially since each paper in this special issue has been through double and in some cases triple blind peer reviews. As the saying goes, we couldn't have done it without you!

Acknowledgements: Our special thanks to Professor Jo Brewis, School of Management, University of Leicester, UK and ex Editor of the journal for reviewing this editorial piece and also for her support and advice over the last two years. 


\section{References}

Avari, B. 2007. India: The ancient past: a history of Indian sub-continent from c. 7000 BC to $A D$ 1200. London: Routledge.

Bandyopadhyay, P. 2011. "Understanding Indianness: Key to Success For Effective HR Interventions in Indian Context", In Debasish Chatterjee, Manoranjan Dhal and TN Krishnan (Eds), HR and Leadership Challenges for Businesses in India, Macmillan Publishers India Ltd, pp. 254-272.

Bandyopadhyay, P. 2015. "HR in Indian Organizations-Is it Different? And is there a need for a different Perspective?" NHRD Network Journal, January, Volume 8(1), pp.78-88.

Buckley, P. J., Enderwick, P., Forsans, N., \& Munjal, S. 2013. Country Linkages and Firm Internationalization: Indian MNEs within Economic-Political Alliances of Nations. In Cook, G. \& Johns, J. (Eds.) The Changing Geography of International Business. Basingstoke, Palgrave MacMillan, pp 79-94.

Durant, W. 1930. The Case for India. Published by Simon and Shuster, New York.

Durant, W. 1935. 'Story of Civilisation, Part 1, The Oriental Heritage', 15th reprint, 1954 (orig. 1934), Published by Simon and Shuster, New York, 391.

Economywatch accessed on $1^{\text {st }}$ March 2015 at http://www.economywatch.com/economicstatistics/.

Geertz, C. 1973. The interpretation of cultures: Selected essays. New York, NY: Basic Books.

Ghosh, A. 2008. Sea of Poppies. London: John Murray.

Giorgi, S., Lockwood, C., \& Glynn, M A. 2015. "The many faces of culture: Making sense of 30 years of research on culture in organization studies." The Academy of Management Annals, 9(1), pp. 1-54.

Hofstede, G. 2007. "Asian management in the 21st century." Asia Pacific Journal of Management, 24: 411-420.

Kuznets, S. 1960. Population Change and Aggregate Output. Demographic and Economic Change in Developed Countries. Universities-National Bureau. Columbia University Press. p. $324-351$.

Jabbar, N. 2011. Historiography and Writing Postcolonial India. UK: Routledge.

Khilnani, S. 2012. The Idea of India. LondonUK: Penguin.

Malik, A., \& Rowley, C. 2015. Business Models and People Management in the Indian IT Industry: From People to profits. UK: Routledge.

Malik, A., Sinha, A., \& Blumenfeld, S. 2012. "Role of quality management capabilities in developing market-based organisational learning capabilities: Case study evidence from four 
Indian business process outsourcing firms", Industrial Marketing Management. 41, 4: 639648.

Malik, A. \& Pereira, V. 2015. "Culture research in India: Critical issues and future research opportunities." In V. Pereira \& A. Malik (eds.) Investigating Cultural Aspects in Indian Organizations - Empirical Evidence. Cham: Springer International Publishing Switzerland.

Malik, Ashish, 2015. "Innovative people management approaches from three software research and product development firms." In A. Malik \& C Rowley, Business Models and People Management in the Indian IT Industry: From People to profits. UK: Routledge.

Markus, Hazel Rose., \& Kitayama, Shinobu. 1991. "Culture and the self: Implications for cognition, emotion, and motivation.” Psychological Review, 98(2), pp. 224-253.

Mill JohnStuart. 1965. Principles of Political Economy. University of Toronto Press

NASSCOM 2014 Strategic Review Report. 2014NASSCOM, Accessed website on $9^{\text {th }}$ September 2014 http://www.nasscom.in/sites/default/files/researchreports/SR14Exec_Summary.pdf.

NASSCOM. 2012. IT-BPO Sector in India: Strategic Review 2010. New Delhi: NASSCOM.

Oyserman, DCoon, H, \& Kemmelmeier, M. 2002. "Rethinking individualism and collectivism: evaluation of theoretical assumptions and meta-analyses." Psychological Bulletin, 128(1), pp. 3-72.

Paul, D \& Amawi, A. 1960. The Theoretical Evolution of International Political Economy, Third Edition: A Reader. Oxford University Press, Business and Economics.

Pereira, V \& Kalakoti, R. 2014. Liberalisation of the Indian retail sector: an examination of macro level HR implications and challenge. International Journal of Indian Culture and Business Management, 9 (4). pp. 468-486. ISSN 1753-0806.

Pereira, V., \& Budhwar, P.. 2015. "HRM and firm performance: the case of Indian IT/BPO industry." In: Malik, Ashish and Rowley, Chris, eds. The changing face of business models and people management in the Indian IT industry: from people to profits. Working in Asia. Routledge, London.

Pereira, V. \& Malik, A. 2015a. Investigating Cultural Aspects in Indian Organizations Empirical Evidence. Cham: Springer International Publishing Switzerland.

Pereira, V., \& Malik, A. 2015b. Human capital management in the Indian IT/BPO industry. London: Palgrave Macmillan.

Pereira, V. 2012. "People and organisational management practices in an emerging market multinational operating in the UK: the case of Tata Consultancy Services." HR Bulletin: Research and Practice, 7 (2). pp. 5-8.

Ryder, A. 1925. The Panchatantra. Chicago: University of Chicago Press 
The Economist, 2010. China's Economy Hello America. Retrieved on $1^{\text {st }}$ March 2015 from http://www.economist.com/node/16834943

Tsui, A. S., Wang, H. \& Xin, K. R. 2006. Organizational Culture in China: An Analysis of Culture Dimensions and Culture Types. Management and Organization Review, 2: 345-376. doi: 10.1111/j.1740-8784.2006.00050.x

Weber, M. 1958. The protestant ethic and the spirit of capitalism. New York, NY: Charles Scribner and Sons. 